\title{
Glucocorticoid Receptor in the Rat Uterus
}

\author{
Masao IZAWA, Yukio SATOH, Kazumi IWASAKI* and Shogo ICHII \\ Division of Physiology, Institute of Steroid Research and Department of \\ Dermatology*, Tottori University School of Medicine, Yonago 683
}

\begin{abstract}
${ }^{3} \mathrm{H}$-Dexamethasone binding sites with a $\mathrm{K}_{\mathrm{d}}$ of $\sim 0.7 \mathrm{nM}$ and a maximum number of binding sites of $\sim 0.3$ pmoles $/ \mathrm{mg}$ protein were demonstrated in the uterine cytosol of adrenalectomized rats only if dithiothreitol was present in the incubation mixture and the simultaneous presence of molybdate further enhanced the binding in the cytosol. The binding sites exhibited a high specificity for glucocorticoids and were depleted in a dose-dependent manner from cytosol after administration of dexamethasone to animals. The depletion was not due to the occupation of the binding sites by the dexamethasone administered and the rate of depletion was correlated with the inhibition of uterine growth induced by estrogen administration. The cytosol labeled with ${ }^{3} \mathrm{H}-$ dexamethasone in the presence of dithiothreitol bound to DNA-cellulose efficiently after heating at $25^{\circ} \mathrm{C}$ for $30 \mathrm{~min}$ and the binding was inhibited by pyridoxal $5^{\prime}$-phosphate added to the reaction mixture. The effect of heating on the DNA-cellulose binding was abolished by molybdate in the incubation mixture.

From these observations, it was concluded that ${ }^{3} \mathrm{H}$-dexamethasone binding sites in the rat uterus were physiologically active glucocorticoid receptors.
\end{abstract}

The presence of cytoplasmic receptors has been considered to be essential in expressing most glucocorticoid responses in target tissues. However, in the rat uterus, inhibition by glucocorticoids of a number of estrogen-induced responses has been well documented (Szego and Roberts, 1953, Szego and Daws, 1969, Campbell, 1978, Markaverich et al., 1981, Stewart et al., 1983), while the lack of glucocorticoid receptors has also been reported (Giannopoulos, 1973, Higgins et al., 1973, Ballard et al., 1974, Booth and Colas, 1975). Recently, Panko et al. (1981) observed ${ }^{3} \mathrm{H}$-glucocorticoid

Received April 16, 1984 binding sites in the rat uterine cytosol with the buffer containing monothioglycerol and examined the physicochemical nature of those binding sites. However, it did not seem to be sufficiently clear whether the binding sites observed by these authors were physiologically active glucocorticoid receptors or not.

In a previous work in this laboratory (Noguchi et al., 1983), it was observed that binding of ${ }^{3} \mathrm{H}$-dexamethasone to the uterine cytosol of rats was markedly enhanced by simultaneous addition of molybdate and dithiothreitol. In the present study, to further elucidate the physiological significance of the ${ }^{3} \mathrm{H}$-dexamethasone binding sites in the rat uterus, some binding characteristics and 
dynamics after administration of glucocorticoid were examined.

\section{Materials and Methods}

\section{Chemicals}

$\left[1,2,4-{ }^{3} \mathrm{H}\right]$ Dexamethasone $\left({ }^{3} \mathrm{H}-D e x\right.$, specific radioactivity, $42 \mathrm{Ci} / \mathrm{mmol}$ ) was purchased from Amersham Internatl. Ltd. (Amersham, UK). Unlabeled steroids were obtained from Sigma Chemical Co. (St. Louis, MO, USA). DNA-cellulose was prepared according to the method of Alberts and Herrick (1971) using calf thymus DNA (Sigma, Type I) and cellulose powder (Whatmann, CF-11, Kent, UK). Other chemicals used were of analytical grade from Nakarai Chemicals Co. (Kyoto, Japan).

\section{Animals and tissue preparations}

Female rats of Wistar strain weighing 180-200 g were mostly used. In experiments where the effect of hormone administration on the cytosolic ${ }^{3} \mathrm{H}$-Dex binding sites was examined, animals were adrenalectomized or adrenalectomized and ovariectomized $12-16$ days prior to using. Hormones were administered subcutaneously as $30 \%$ ethanol-saline solutions. To prepare cytosols, tissues were homogenized in 5 (liver and thymus) or 10 (uterus) volumes of ice-cold TEM buffer solution (10 mM Tris-HCI, pH 7.4, 0.5 mM EDTA and $2 \mathrm{mM}$ 2-mercaptoethanol) supplemented with or without $10 \mathrm{mM}$ sodium molybdate (Mo) and $10 \mathrm{mM}$, dithiothreitol (DTT). Homogenates were centrifuged at $10,5000 \times \mathrm{g}$ for $1 \mathrm{~h}$ and the resultant supernatant was used as cytosol after treatment with $1 / 3$ volume of dextran-coated charcoal (DCC, $2.5 \%$ charcoal $-0.25 \%$ dextran in TEM buffer) to remove free steroids.

Determination of ${ }^{3} \mathrm{H}$-Dex binding sites in cytosols

Aliquots of cytosol were incubated with a series concentration of ${ }^{3} \mathrm{H}$-Dex $(1-10 \mathrm{nM})$ in the presence or absence of 500-fold molar excess of unlabeled dexamethasone (Dex) in a final volume of $0.4 \mathrm{ml}$ at $0^{\circ} \mathrm{C}$ for $15 \mathrm{~h}$. At the end of incubation, unbound steroids were removed with $0.2 \mathrm{ml}$ of $\mathrm{DCC}$ at $0^{\circ} \mathrm{C}$ for $15 \mathrm{~min}$ and the radioactivity in an aliquot of the supernatant was determined after brief centrifugation. The radioactivity which was not displaced by the addition of 500 -fold molar excess of radioinert Dex was referred to as the non-specific binding and subtracted in all instances. The dissociation constant $\left(\mathrm{K}_{\mathrm{d}}\right)$ and number of maximum binding sites $\left(B_{\max }\right)$ were calculated by the method of Scatchard (1949). Rates of inhibition by radioinert steroids and diethylstilbestrol were estimated as described previously (Izawa and Ichii, 1978). Exchange assay of glucocorticoid-bound cytosol was performed by the method of Banerji and Kalimi (1981) using p-hydroxymercuribenzoate and DTT.

\section{Binding to DNA-cellulose of uterine cytosol labeled} with ${ }^{3} \mathrm{H}$-Dex

The cytosol was incubated with $20 \mathrm{nM}{ }^{3} \mathrm{H}$-Dex in the TEM buffer supplemented with $20 \mathrm{mM}$ DTT at $0^{\circ} \mathrm{C}$ for $4 \mathrm{~h}$ and treated with DCC to remove unbound ligands. The ${ }^{3} \mathrm{H}-\mathrm{Dex}$ labeled cytosol was incubated at $25^{\circ} \mathrm{C}$ for $30 \mathrm{~min}$, in the presence or absence of $10 \mathrm{mM} \mathrm{Mo}$, and cooled in ice for $30 \mathrm{~min}$. An aliquot of the labeled cytosol was incubated with the DNA-cellulose (40 mg powder containing $130 \mu \mathrm{g}$ DNA) in a total volume of $1 \mathrm{ml}$ at $0^{\circ} \mathrm{C}$ for $30 \mathrm{~min}$ with occasional vortexing. At the end of the incubation period, after a brief centrifugation at $3000 \times \mathrm{g}$ the supernatant was discarded. The pelleted DNA-cellulose was washed twice with $1.5 \mathrm{ml}$ of the TEM buffer, the bound steroid was extracted with $1.5 \mathrm{ml}$ of ethanol and the radioactivity was determined. In a parallel incubation, the radioactivity associated with plain cellulose was determined and subtracted from that associated with DNA-cellulose as the non-specific binding.

\section{Analytical methods}

Protein and DNA were determined by the methods of Lowry et al. (1951) and Burton (1968) using bovine serum albumin and calf thymus DNA as standards, respectively. The radioactivity was determined in a liquid scintillation spectrometer (Aloka, LSC-700) with automatic standardization for quenching correction.

\section{Results}

Binding parameters and specificity of ${ }^{3} \mathrm{H}$-Dex. binding to uterine cytosol

As reported previously (Noguchi et al., 1983), ${ }^{3} \mathrm{H}$-Dex binding to uterine cytosols was synergistically enhanced when both Mo and DTT were included in the incubation 


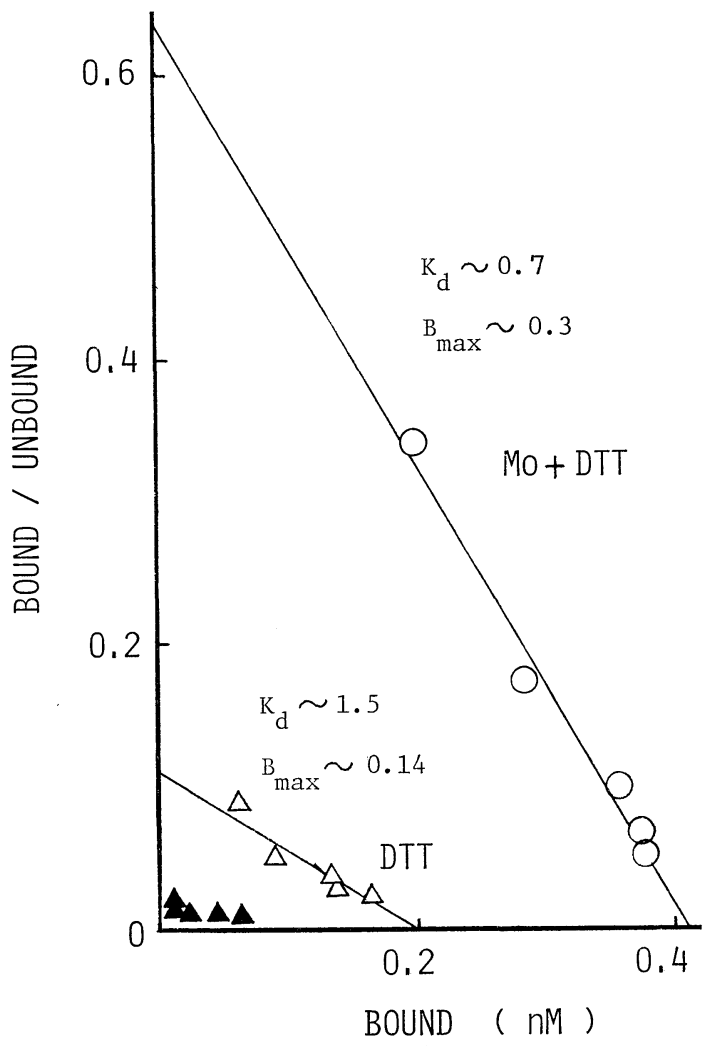

Fig. 1. Scatchard plot of ${ }^{3} \mathrm{H}$-Dex binding in the uterine cytosol of adrenalectomized rats.

Binding of ${ }^{3} \mathrm{H}$-Dex in the cytosol from uterus of adrenalectomized rats was assayed in the TEM buffer (Fig. 1, $\mathbf{\Delta}$ ), in the buffer containing DTT $(10 \mathrm{mM})$ (Fig. $1, \triangle)$ and in the buffer containing DTT $(10 \mathrm{mM})$ and Mo $(10 \mathrm{mM})$ (Fig. $1, \bigcirc$ ). $K_{d}$ and the number of maximum binding sites are indicated in the figure as $\mathrm{nM}$ and pmoles per mg protein, respectively.

mixture of the binding experiments (Fig. 1); in the presence of Mo and DTT, $K_{d}$ and number of maximum binding sites were approximately $0.7 \mathrm{nM}$ and 0.3 pmoles per $\mathrm{mg}$ protein, respectively. Steroid specificity of the binding observed in the presence of Mo and DTT was also examined (Fig. 2). Steroids which possess the biological potency of glucocorticoid showed high rates of inhibition of ${ }^{3} \mathrm{H}$-Dex binding, and progesterone inhibited the binding moderately, while estro-
Table 1. Binding to DNA-cellulose of the uterine cytosol labeled with ${ }^{3} \mathrm{H}$-Dex.

\begin{tabular}{clc}
\hline $\begin{array}{c}\text { Pretreatment of } \\
{ }^{3} \mathrm{H}-\text { Dex labeled } \\
\text { cytosol }\end{array}$ & $\begin{array}{c}\text { Conditions for } \\
\text { DNA-cellulose } \\
\text { binding** }\end{array}$ & $\begin{array}{c}\text { Bound } \\
\text { radio- } \\
\text { activity*** }\end{array}$ \\
\hline $0^{\circ} \mathrm{C}$ for $30 \mathrm{~min}$ & $0^{\circ} \mathrm{C}$ for $30 \mathrm{~min}$ & $520 \mathrm{dpm}$ \\
$25^{\circ} \mathrm{C}$ for $30 \mathrm{~min}$ & $0^{\circ} \mathrm{C}$ for $30 \mathrm{~min}$ & 2675 \\
$25^{\circ} \mathrm{C}$ for $30 \mathrm{~min}$ & $\begin{array}{l}0^{\circ} \mathrm{C} \text { for } 30 \mathrm{~min} \\
\text { in the presence of }\end{array}$ & 710 \\
& $\begin{array}{l}10 \mathrm{mM} \text { pyridoxal } \\
5^{\prime} \text {-phosphate }\end{array}$ \\
$25^{\circ} \mathrm{C}$ for $30 \mathrm{~min}$ & $0^{\circ} \mathrm{C}$ for $30 \mathrm{~min}$ & 335 \\
in the presence of & & \\
$10 \mathrm{mM} \mathrm{Na} \mathrm{MoO}_{4}$ &
\end{tabular}

Uterine cytosol from adrenalectomized rats was incubated with $20 \mathrm{nM}$ of ${ }^{3} \mathrm{H}-\mathrm{Dex} \pm 500$-fold molar excess of unlabeled Dex in the presence of DTT $(20 \mathrm{mM})$ at $0^{\circ} \mathrm{C}$ for $4 \mathrm{~h}$ and the labeled cytosol was prepared by the DCC method described in the "Materials and Methods".

* The ${ }^{3} \mathrm{H}$-Dex labeled cytosol was pretreated as indicated in the Table and an aliquot of each (19758 dpm, $0.63 \mathrm{mg}$ as protein) was used for the DNA-cellulose binding experiments.

** $1 \mathrm{ml}$ of the assay mixture contained $40 \mathrm{mg}$ of DNA-cellulose (130 $\mu \mathrm{g}$ as DNA) or plain cellulose and the labeled cytosol described above.

*** Bound radioactivity was obtained by subtracting the radioactivity bound to plain cellulose from that bound to DNA-cellulose. Results obtained in the additional two experiments were almost identical. For other experimental conditions, see the "Materials and Methods".

gen and androgen did not show any significant inhibitory effect. The binding specificity observed was a typical one which has been reported in glucocorticoid-receptor systems of target tissues (Izawa and Ichii, 1978, Noguchi et al., 1983).

Binding to DNA-cellulose of uterine cytosol labeled with ${ }^{3} \mathrm{H}$-Dex in the presence of DTT

The uterine cytosol was prepared from adrenalectomized rats in the TEM buffer and incubated with $20 \mathrm{nM}$ of ${ }^{3} \mathrm{H}$-Dex in the presence of $10 \mathrm{mM} \mathrm{DTT}$ at $0^{\circ} \mathrm{C}$ for $4 \mathrm{~h}$. At the end of the incubation, unbound ligands 


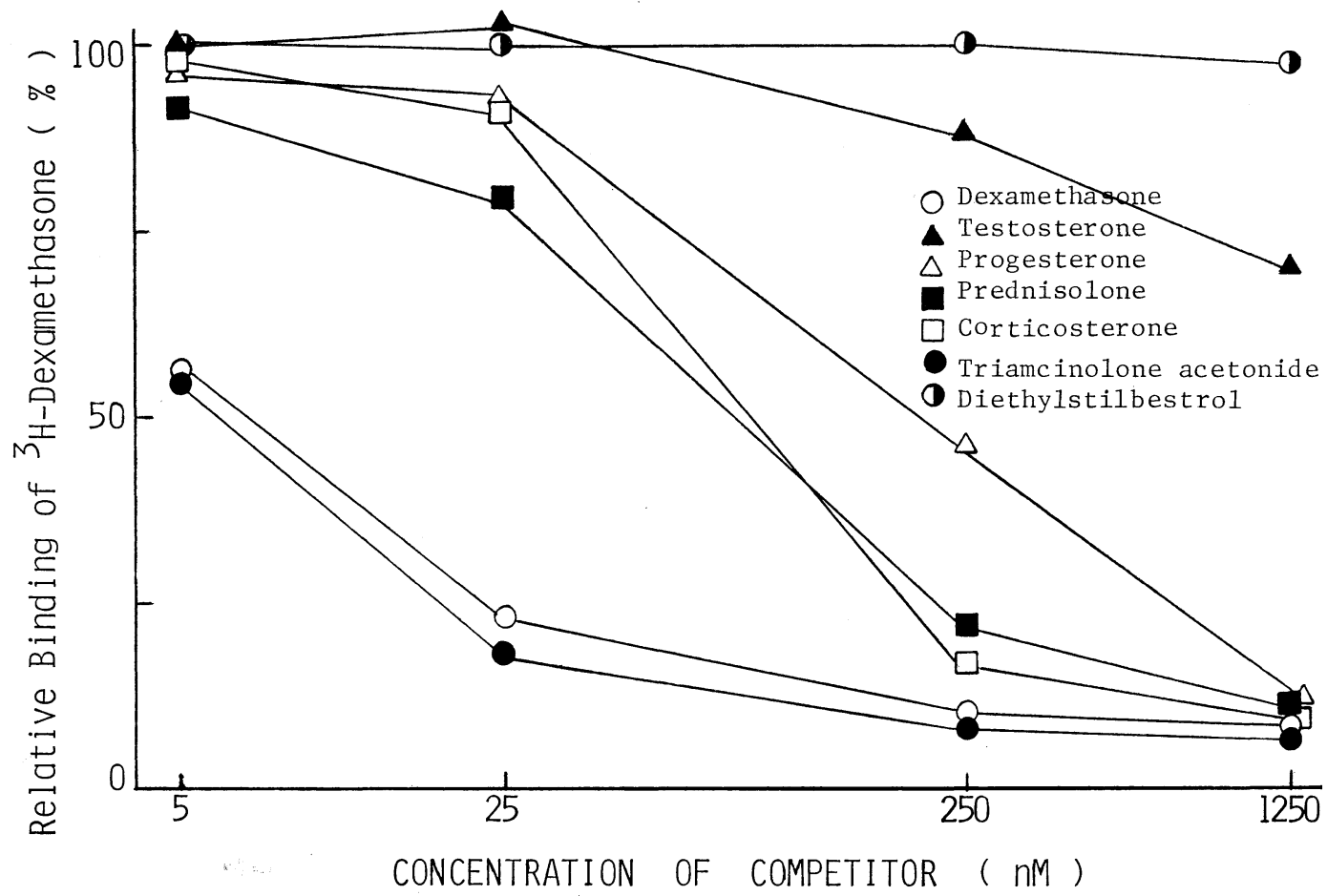

Fig. 2. Steroid specificity of the ${ }^{3} \mathrm{H}$-Dex binding in the uterine cytosol. An aliquot of the uterine cytosol (1.1 $\mathrm{mg}$ as protein) prepared in the TEM buffer supplemented with DTT (10 $\mathrm{mM})$ and Mo $(10 \mathrm{mM})$ was incubated with ${ }^{3} \mathrm{H}$-Dex $(4.7 \mathrm{nM})$ at $0^{\circ} \mathrm{C}$ for $15 \mathrm{~h}$ in a final volume of $0.4 \mathrm{ml}$. To estimate the inhibitory effect of unlabeled competitors, various concentrations of competitors were added to the incubation mixtures as ethanol solutions at concentrations of ethanol less than $0.2 \%$ in all instances. The binding in the absence of competitor was $16700 \mathrm{dpm} /$ tube.

were removed by the DCC method. The labeled cytosol was divided into two parts and further incubated at $25^{\circ} \mathrm{C}$ for $30 \mathrm{~min}$ in the presence or absence of $10 \mathrm{mM}$ Mo. An aliquot of the heated cytosol was incubated with DNA-cellulose at $0^{\circ} \mathrm{C}$ for 30 min and the ${ }^{3} \mathrm{H}$-Dex bound to DNA-cellulose was determined. The labeled cytosol heated at $25^{\circ} \mathrm{C}$ in the absence of Mo bound to DNA-cellulose, but the cytosol heated in the presence of Mo did not show any sign of binding to DNA-cellulose (Table 1). The addition of pyridoxal $5^{\prime}$-phosphate to the reaction mixture markedly reduced the binding of the cytosol heated in the absence of Mo to DNA-cellulose.
Depletion of ${ }^{3} H$-Dex binding sites in uterine cytosol after administration of Dex

Depletion of the cytoplasmic receptor after steroid hormone administration has been attributed to translocation of receptors to nuclei following binding with steroid hormones. Therefore, the depletion of the cytoplasmic receptor seems to be one of the indices to be used in evaluating the physiological roles of the binding sites for steroid hormones. For this reason, changes in the binding sites for ${ }^{3} \mathrm{H}$-Dex $30 \mathrm{~min}$ after Dexadministration were examined (Fig. 3). $\mathrm{K}_{\mathrm{d}}$ 's were not changed with the dose of Dex administered (approximately $0.7 \mathrm{nM}$ ), while $B_{\max }$ 's of ${ }^{3} \mathrm{H}$-Dex binding sites were de- 


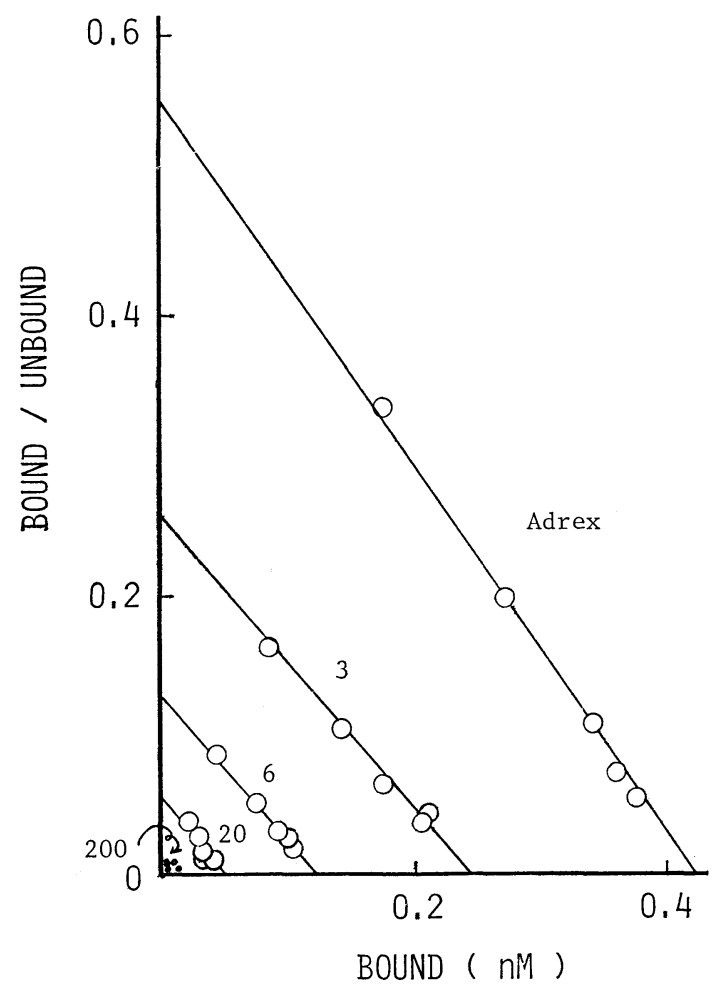

Fig. 3. Changes in the ${ }^{3} \mathrm{H}$-Dex binding sites of uterine cytosol from adrenalectomized rats after administration of Dex.

Adrenalectomized rats were injected with 3, 6, 20 and $200 \mu \mathrm{g}$ per head of Dex $30 \mathrm{~min}$ before sacrifice. Cytosols were prepared in the TEM buffer supplemented with Mo (10 $\mathrm{mM})$ and DTT $(10 \mathrm{mM})$ and aliquots (approximately $0.6 \mathrm{mg}$ as protein per tube) were incubated with series concentrations of ${ }^{3} \mathrm{H}$-Dex $(1-10 \mathrm{nM})$ in a final volume of $0.4 \mathrm{ml}$ at $0^{\circ} \mathrm{C}$ for $15 \mathrm{~h}$. Specific bindings were analyzed by the method of Scatchard (1949). For other experimental conditions, see the "Materials and Methods".

creased in a dose-dependent manner (no injected control, 0.31, Dex $3 \mu \mathrm{g}, 0.14$, Dex $6 \mu \mathrm{g}, 0.08$, Dex $20 \mu \mathrm{g}, 0.03 \mathrm{pmoles} / \mathrm{mg}$ protein, respectively, Dex $200 \mu \mathrm{g}$, not detectable). To ascertain whether the depletion is merely due to the occupation of the binding sites by Dex administration, the
Table 2. Effect of adrenalectomy, ovariectomy and estradiol-17 $\beta$ administration on ${ }^{3} \mathrm{H}-\mathrm{Dex}$ binding in the uterine cytosol.

\begin{tabular}{lrcc}
\hline \hline $\begin{array}{l}\text { Treatment of } \\
\text { animals }\end{array}$ & $\begin{array}{c}\text { No. of } \\
\text { Exp. }\end{array}$ & $\begin{array}{c}{ }^{3} \mathrm{H}-\mathrm{Kd} \\
\text { (nM) }\end{array}$ & $\begin{array}{c}\text { binding* } \\
\text { (pmoles/mg } \\
\text { protein) }\end{array}$ \\
\hline None & 8 & $0.57 \pm 0.02$ & $0.29 \pm 0.01$ \\
Adrex, 8 days & 7 & $0.65 \pm 0.05$ & $0.31 \pm 0.01$ \\
Adrex \& Ovex, 8 days 3 & $0.67 \pm 0.03$ & $0.30 \pm 0.03$ \\
$\begin{array}{l}\text { Adrex \& Ovex, 12 days 3 } \\
\text { Adrex \& Ovex, 12 days } \\
\text { plus E2-17 } \beta(20 \mu \mathrm{g} / \text { day), 4 } 4\end{array}$ & $0.62 \pm 0.06$ & $0.32 \pm 0.02$ \\
2 days & $0.29 \pm 0.01$ \\
\hline
\end{tabular}

* Values are expressed as means $\pm \mathrm{SEM}$.

Uterine cytosols were prepared from animals which had been adrenaectomized, ovariectomized and treated with estradiol- $17 \beta$ as indicated in the Table. Binding parameters for ${ }^{3} \mathrm{H}-\mathrm{Dex}$ of uterine cytosol were determined by the method of Scatchard (1949) as described in the "Materials and Methods".

exchange assay developed by Banerji and Kalimi (1981) was applied to the uterine cytosol prepared from animals which received $200 \mu \mathrm{g}$ per head of Dex $30 \mathrm{~min}$ before. In this cytosol, no significant binding of ${ }^{3} \mathrm{H}$-Dex to the cytosol was detected even by the exchange assay (data not shown). These results indicated that the depletion of ${ }^{3} \mathrm{H}$ Dex binding sites in the uterine cytosol after Dex administration seemed to be the consequence of nuclear translocation of the receptor-complexes which were commonly observed in steroid-receptor systems of various target tissues (Anderson et al., 1975, Bloom et al., 1980, Freifeld et al., 1974, Ichii, 1980, 1981, Isomaa et al., 1979, Isotalo et al., 1981, Kassis and Gorski, 1981, Mester and Baulieu, 1975, Milgrom et al., 1973, Walters and Clark, 1978).

Effects of adrenalectomy, ovariectomy and estradiol administration on ${ }^{3} \mathrm{H}$-Dex binding sites in the uterine cytosol

The binding capacity to ${ }^{3} \mathrm{H}-\mathrm{Dex}$ in the 

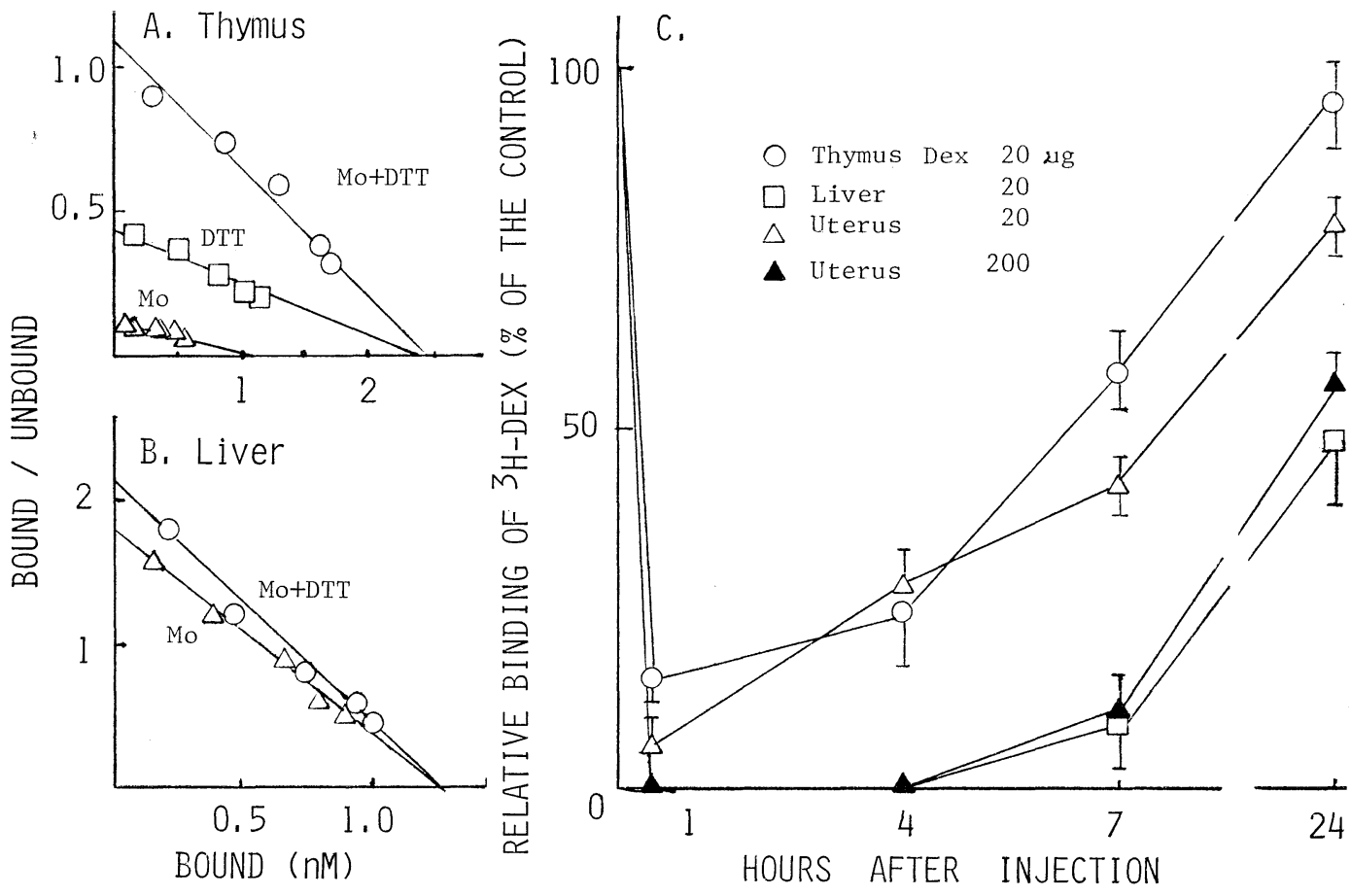

Fig. 4. Depletion and replenishment of ${ }^{3} \mathrm{H}$-Dex binding sites in cytosols from the liver, thymus and uterus after administration of Dex. Adrenalectomized rats were sacrificed at appropriate time intervals after administration of Dex (doses are indicated in Fig. 4-C as $\mu \mathrm{g} / \mathrm{head}$ ) and cytosols of three tissues were prepared in the TEM buffer supplemented with DTT $(10 \mathrm{mM})$ and Mo $(10 \mathrm{mM})$. Binding of ${ }^{3} \mathrm{H}-\mathrm{D} 2 x$ in cytosols of the uterus (Fig. 1), thymus (Fig. 4-A) and liver (Fig. 4-B) was assayed in the TEM buffer containing Mo (10 mM) and DTT (10 mM). Aliquots of cytosols (liver, 0.9, thymus, 0.7 and uterus, $0.6 \mathrm{mg}$ as protein per tube, respectively) were incubated with series concentrations of ${ }^{3} \mathrm{H}$-Dex $(1-10 \mathrm{nM})$ in a final volume of $0.4 \mathrm{ml}$ at $0^{\circ} \mathrm{C}$ for $15 \mathrm{~h}$. Binding parameters were determined by the method of Scatchard (1949). Binding sites for ${ }^{3} \mathrm{H}-\mathrm{Dex}$ in cytosols from uninjected adrenalectomized rats were taken as 100 (liver, 0.53, thymus, 1.23 and uterus, 0.31 pmoles per mg protein, respectively) and values were expressed as the relative bindings of the controls (mean \pm SEM) in at least 3 experiments performed independently. For other experimental conditions, see the "Materials and Methods".

cytosol was not significantly altered after adrenalectomy, ovariectomy or estrogen administration during the experimental periods (Table 2). $\quad \mathrm{K}_{\mathrm{d}}$ 's for ${ }^{3} \mathrm{H}$-Dex were not altered significantly by any of the treatments described above.
Comparison of the pattern of depletion ana replenishment of ${ }^{3} \mathrm{H}$-Dex binding sites in cytosols from the uterus after administration of Dex with those of the liver and thymus

The time-course of the depletion of the binding sites was compared in these tissues (Fig. 4-C). As reported by Sando et al. (1979), ${ }^{3}$ H-Dex binding to the thymus cytosol was significantly enhanced by Mo and 
DTT and it was observed that these reagents act to increase the binding affinity as well as the binding sites of the cytosol to ${ }^{3} \mathrm{H}-$ Dex (Fig. 4-A). The effect of Mo and DTT on ${ }^{3} \mathrm{H}$-Dex binding to the liver cytosol was relatively small (Fig. 4-B). Therefore, Mo and DTT were included in the reaction mixtures of ${ }^{3} \mathrm{H}$-Dex binding to cytosols in this study. Within $30 \mathrm{~min}$ after injections of $20 \mu \mathrm{g}$ of Dex, the shortest period examined, maximum depletions of ${ }^{3} \mathrm{H}$-Dex binding sites in cytosols from all tissues were observed but rates of depletion of the binding sites in these tissues were slightly different; in the liver, the binding sites completely disappeared, while $15 \%$ and $5 \%$ of the binding sites of the uninjected controls still remained in the thymus and uterus. The patterns of replenishment were also different significantly in these 3 tissues; in the thymus and uterus, the binding sites were replenished to approximately $50 \%$ of the untreated controls by $7 \mathrm{~h}$ after treatment with $20 \mu \mathrm{g}$ of Dex, while in the liver, only $10 \%$ of the binding sites of the control were observed at this time. Replenishment of the binding sites in the uterine cytosol was much more rapid than that in the liver cytosol; in the uterine cytosol from animals which received $200 \mu \mathrm{g}$ of Dex, the rate of replenishment was higher than that observed in the liver cytosol of animals which had received $20 \mu \mathrm{g}$ of Dex. The physiological significance of the rapid replenishment of the binding sites observed in the uterine cytosol is not clear at the present moment.

Effect of addition of uterine cytosol on ${ }^{3} \mathrm{H}$ Dex binding to liver cytosol

In our previous study (Izawa et al., 1984), the presence of cytosolic inhibitor(s) which specifically inhibits the ${ }^{3} \mathrm{H}$-Dex binding was demonstrated in cytosols of the male accessory sex organs and a similar inhibitor(s) in the uterine cytosol was also suggested. When the uterine cytosol prepared from animals injected with $200 \mu \mathrm{g}$ of Dex $30 \mathrm{~min}$

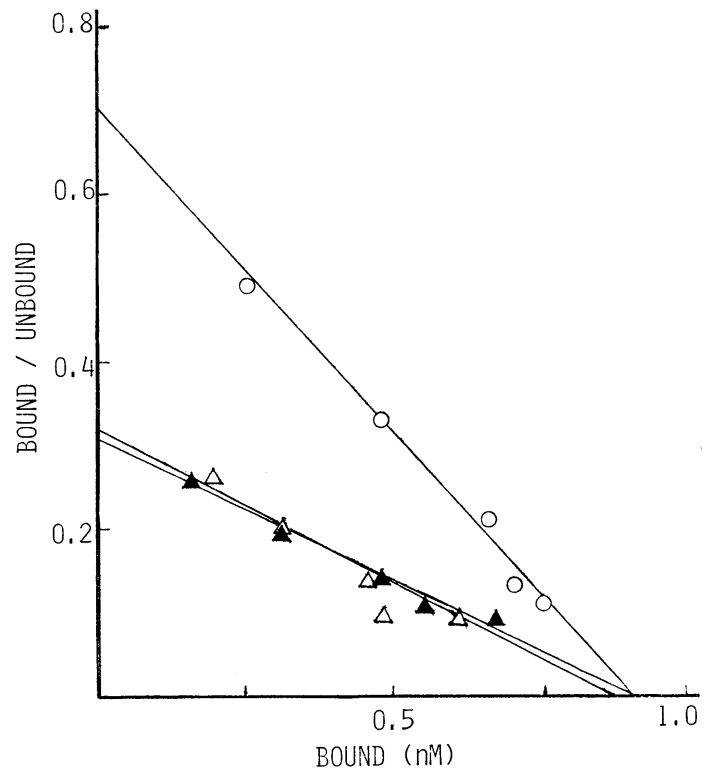

Fig. 5. Effect of the uterine cytosol on ${ }^{3} \mathrm{H}$-Dex binding in the liver cytosol. Liver cytosol from female adrenalectomized rats $(0.9 \mathrm{mg}$ as protein) prepared in the TEM buffer supplemented with Mo $(10 \mathrm{mM})$ was incubated with increasing concentrations of ${ }^{3} \mathrm{H}$-Dex (1-10 nM) \pm 500 -fold molar excess of unlabeled Dex in the presence or absence of the DCC-treated uterine cytosol $(0.6 \mathrm{mg}$ as protein) or the cytosol heated at $60^{\circ} \mathrm{C}$ for $15 \mathrm{~min}$, prepared from animals which received $200 \mu \mathrm{g}$ per head of Dex $30 \mathrm{~min}$ prior to sacrifice, in a final volume of $0.4 \mathrm{ml}$ at $0^{\circ} \mathrm{C}$ for $15 \mathrm{~h}$. At the end of the incubation period, unbound steroids were removed with $0.2 \mathrm{ml}$ of the DCC and the bound radioactivity in an aliquot of the supernatant was measured. $\mathrm{K}_{\mathrm{d}}$ and number of maximum binding sites were determined by the method of Scatchard (1949). $\mathrm{K}_{\mathrm{d}}$ 's are $1.3(\bigcirc$, control), $2.8(\triangle$, untreated uterine cytosol) and $3.0 \mathrm{nM}(\boldsymbol{\Delta}$, heated uterine cytosol), respectively. The maximum binding site was approximately 0.5 pmoles per $\mathrm{mg}$ protein in all instances. For other experimental conditions, see the "Materials and Methods".

before sacrifice was added to the liver cytosol from adrenalectomized rats, $\mathrm{K}_{\mathrm{d}}$ was elevated from 1.3 to $3.0 \mathrm{nM}$ without any 
change in the number of maximum binding sites (Fig. 5, approximately 0.50 pmoles $/ \mathrm{mg}$ liver protein). Pretreatment of the uterine cytosol at $60^{\circ} \mathrm{C}$ for $15 \mathrm{~min}$ did not alter the inhibitory activity significantly. These results are essentially consistent with the observation in experiments of cytosols from male accessory sex organs (Izawa et al., 1984). From these observations, it seems that an inhibitor(s) of which activity is inactivated by the addition of Mo and DTT is also present in the uterus.

Effect of Dex administration on the uterine growth induced by estradiol-17 $\beta$ administration

As reported by Markaverich et al. (1981), estrogen administration evoked significant uterine growth, and simultaneous injection of Dex reduced the rate of uterine growth induced by estradiol. To examine the role of ${ }^{3} \mathrm{H}$-Dex binding sites of the uterine cytosol in glucocorticoid antagonism of the uterotropic responses to estrogens, various doses of Dex and $20 \mu \mathrm{g}$ of estradiol- $17 \beta$ were administered simultaneously to adrenalectomized and ovariectomized rats and the uterine wet weight was estimated $24 \mathrm{~h}$

Table 3. Effect of Dex administration on uterine growth induced by estradiol-17 $\beta$ administration

\begin{tabular}{lrr}
\hline Treatment of animals* & $\begin{array}{c}\text { No. of } \\
\text { Exp. }\end{array}$ & $\begin{array}{c}\text { Uterine wet } \\
\text { weight }(\mathrm{mg})^{* *}\end{array}$ \\
\hline None & 13 & $80.5 \pm 4.1$ \\
$\mathrm{E}_{2}(20 \mu \mathrm{g})$ & 4 & $181.5 \pm 10.0$ \\
$\mathrm{E}_{2}(20 \mu \mathrm{g}) \&$ Dex $(20 \mu \mathrm{g})$ & 4 & $145.0 \pm 8.0$ \\
$\mathrm{E}_{2}(20 \mu \mathrm{g}) \&$ Dex $(200 \mu \mathrm{g})$ & 4 & $124.5 \pm 6.5$ \\
$\mathrm{E}_{2}(20 \mu \mathrm{g}) \&$ Dex $(500 \mu \mathrm{g})$ & 4 & $104.7 \pm 8.1$ \\
\hline
\end{tabular}

* Rats (weighing 190-210 g) which had been adrenalectomized and ovariectomized for 12-16 days received subcutaneous injections of estradiol-17 $\beta$ $\left(\mathrm{E}_{2}\right)$ and Dex at doses indicated in the Table (per head) in 30\% ethanol-saline solution.

** Uterine wet weight was estimated $24 \mathrm{~h}$ after administration of hormones. Values are expressed as means \pm SEM. after hormone injection (Table 3). In the present study, complete inhibition was not observed even after treatment of animals with $500 \mu \mathrm{g}$ of Dex. On the other hand, estrogen administration did not alter the pattern of depletion and replenishment of the ${ }^{3} \mathrm{H}$-Dex binding sites in the uterine cytosol (data not shown).

\section{discussion}

The addition of Mo and DTT enabled us to examine the nature of ${ }^{3} \mathrm{H}$-Dex binding sites in the uterine cytosol. Similar ${ }^{3} \mathrm{H}$-Dex binding systems have already been recognized in the male accessary sex organs; the binding sites for ${ }^{3} \mathrm{H}$-Dex are detected only if DTT is present in the incubation mixture and the simultaneous presence of Mo enhances the binding in cytosols from those tissues (Noguchi et al., 1983). The presence of at least two different inhibiting factors for ${ }^{3} \mathrm{H}$-Dex binding, one related to DTT and the other sensitive to Mo, is suggested by these results. Inhibiting factors for ${ }^{3} \mathrm{H}$-Dex binding have also been detected in the uterine cytosol (Fig. 5, Izawa et al., 1984). Therefore, it seems probable that the inhibiting factors mask the binding sites for ${ }^{3} \mathrm{H}$-Dex during the period of tissue processing in vitro. The addition of $\mathrm{Mo}$ and DTT abolished the action of the inhibiting factors and the demasked binding sites become detectable.

Characteristics of the ${ }^{3} \mathrm{H}$-Dex binding sites in the uterine cytosol examined in the presence of Mo and DTT are well fitted to the definition proposed for the steroid hormone receptors; the binding sites are high affinity $\left(\mathrm{K}_{\mathrm{d}} \sim 0.7 \mathrm{nM}\right.$ for Dex $)$ and limited number $\left(\mathrm{B}_{\max } \sim 0.3 \mathrm{pmoles} / \mathrm{mg}\right.$ protein) and exhibit a high specificity for glucocorticoids. Upon binding to the ligand, the binder in the uterine cytosol aquires the ability to bind to DNA-cellulose after brief heating. Furthermore, the binding sites in the cytosol 
are depleted after administration of Dex. Depletion of the cytoplasmic receptor after steroid hormone administration has been attributed to the translocation of steroid hormone-receptor complexes to nuclei. Therefore, dose-dependent depletion of the ${ }^{3} \mathrm{H}$-Dex binding sites observed after administration of Dex in the uterine cytosol seems to be a line of evidence showing that the binder may have some physiological activity in that tissue.

Another unique feature of the present study is in finding that replenishment of the binding sites in the uterine cytosol takes place rapidly following the depletion induced by Dex administration. The period of depletion is dependent on the dose of hormone administered and varies from tissue to tissue (Figs. 3 and 4, Ichii, 1981). The replenishment in the uterine cytosol of animals which received $200 \mu \mathrm{g}$ per head of Dex is faster than that in the liver cytosol of animals treated with $20 \mu \mathrm{g}$ of Dex. The length of the receptor depletion is well correlated with the amount of tyrosine aminotransferase induction in the liver (Izawa et al., 1982). It has been considered that the biological action of glucocorticoid as well as that of androgen (Ichii, 1980) is exerted during the period of receptor depletion. The administration of Dex blocks the uterine growth induced by estradiol but complete inhibition is not attained even with the highest dose 'examined $(500 \mu \mathrm{g} /$ head, Table 3). This may be explained, at least in part, by the fact that the ${ }^{3} \mathrm{H}$-Dex binding sites in the uterine cytosol replenish rapidly. Therefore, it may require higher dose of or more frequent injections of Dex to maintain the level of the binding sites in a depleted state. Factors which determine the length of receptor depletion in tissues, except the dose of hormone administered, have not been examined and may provide subjects to be explored.

\section{References}

Alberts, B. and G. Herrick (1971). DNA-cellulose chromatography, Meth. Enzymol. 21 D, 198-217.

Anderson, J. N., E. J. Peck and J. H. Clark (1975). Estrogen induced uterine responses and growth: Relationship to receptor-estrogen binding by uterine nuclei. Endocrinology 96, 160-167.

Ballard, P. L., J. D. Baxter, S. J. Higgins, G. G. Rousseau and G. M. Tomkins (1974). General presence of glucocorticoid receptors in mammalian tissues. Endocrinology 94, 998-1002.

Banerji, A. and M. Kalimi (1981). Development of an ${ }^{3} \mathrm{H}$-glucocorticoid exchange assay in rat liver cytosol. Steroids 37, 409-421.

Bloom, E., D. T. Matulich, N. C. Lan, S. J. Higgins, S. S. Simons and J. D. Baxter (1980). Nuclear binding of glucocorticoid receptors : Relations between cytosol binding, activation and biological response. J. Steroid Biochem. 12, 175-184.

Booth, B. A. and A. E. Colas (1975). Binding interactions of progesterone and other C 21 steroids with rat uterine cytosol. Gynecol. Invest. 6, 272-284.

Burton, K. (1968). Determination of DNA concentration with diphenylamine. Meth. Enzymol. 12 B, 163-166.

Campbell, P. S. (1978). The mechanism of the inhibition of uterotropic responses by acute dexamethasone pretreatment. Endocrinology 103, 716-723.

Freifeld, M. L., P. D. Feil and C. W. Bardin (1974). The in vivo regulation of progesterone "receptor" in guinea pig uterus: Dependence on estrogen and progesterone. Steroids 23, 93-103.

Giannopoulos, G. (1973). A specific glucocorticoid binding macromolecule of rabbit uterine cytosol. Biochem. Biophys. Res. Commun. 54, 600-606.

Higgins, S. J., G. G. Rousseau, J. D. Baxter and G. M. Tomkins (1973). Nature of the nuclear acceptor sites for glucocorticoid and estrogen receptor complexes. J. Biol. Chem. 248, 58735879.

Ichii, S. (1980). Changes in the cytoplasmic androgen receptor of rat ventral prostate after administration of androgens, anti-androgens and anabolic steroids. Endocrinol. Japon. 27, 483493.

Ichii, S. (1981). Depletion and replenishment of 
glucocorticoid receptors in cytosols of rat tissues after administration of various glucocorticoids. Endocrinol. Japon. 28, 293-304.

Isomaa, V., H. Isotalo, M. Orava and O. Jänne (1979). Regulation of cytosol and nuclear progesterone receptor in rabbit uterus by estrogen, antiestrogen and progesterone administration. Biochim. Biophys. Acta 585, 24-33.

Isotalo, H., V. Isomaa and O. Jänne (1981). Replenishment and properties of cytosol progesterone receptor in rabbit uterus after multiple progesterone administration. Endocrinology 108, 868-873.

Izawa, M. and S. Ichii (1978). Further studies on the cytoplasmic ${ }^{3} \mathrm{H}$-dexamethasone receptor in the liver from adult and fetal rats. Endocrinol. Japon. 25, 561-568.

Izawa, M., A. Yoshida and S. Ichii (1982). Dynamics of glucocorticoid receptor and induction of tyrosine aminotransferase in rat liver. Endocrinol. Japon. 29, 209-218.

Izawa, M., Y. Satoh and S. Ichii (1984). Cytoplasmic inhibiting factors for ${ }^{3} \mathrm{H}$-dexamethasone binding to glucocorticoid receptors in rat tissues. Endocrinol. Japon., 31, 471-482.

Kassis, J. and J. Gorski (1981). Estrogen receptor replenishment: Evidence for recycling. J. Biol. Chem. 256, 7378-7382.

Lowry, O. H., N. J. Rosebrough, A. L. Farr and R. J. Randall (1951). Protein measurement with the Folin phenol reagent. J. Biol. Chem. 193, 265-275.

Markaverich, B. M., S. Upchurch and J. H. Clark (1981). Progesterone and dexamethasone antagonism of uterine growth: A role for a second nuclear binding site for estradiol in estrogen action. J. Steroid Biochem. 14, 125-132.
Mester, J. and E. E. Baulieu (1975). Dynamics of oestrogen-receptor distribution between the cytosol and nuclear fractions of immature rat uterus after oestradiol administration. Biochem. J. 146, 617-623.

Noguchi, T., M. Izawa and S. Ichii (1983). Binding sites for glucocorticoids in cytosols from the ventral prostate and seminal vesicle of rats. Endocrinol. Japon. 30, 513-521.

Panko, W. B., J. H. Clark and M. R. Walters (1981). Glucocorticoid receptors : Documentation in the rat uterus. J. Receptor Res. 2, 29-45.

Sando, J. J., N. D. Hammond, C. A. Stratford and W. B. Pratt (1979). Activation of thymocyte glucocorticoid receptors to the steroid binding form: The role of reducing agent, ATP and heat-stable factors. J. Biol. Chem. 254, 4779-4789.

Scatchard, G. (1949). The attraction of protein for small molecules and ions. Ann. N. Y. Acad. Sci. 51, 660-672.

Stewart, P. J., C. J. Zaloudek, M. Murphy Inman and R. A. Webster (1983). Effects of dexamethasone and indomethacin on estrogeninduced uterine growth. Life Sci. 33, 23492356.

Szego, C. M. and S. Roberts (1953). Steroid action and interaction in uterine metabolism. Rec. Prog. Horm. Res. 8, 419-469.

Szego, C. M. and J. S. Davis (1969). Inhibition of estrogen induced cyclic AMP elevation in rat uterus II : By glucocorticoids. Life Sci. 8, 1109-1116.

Walters, M. R. and J. H. Clark (1978). Stoichiometric translocation of the rat uterine progesterone receptor. Endocrinology 103, 1952-1955. 